\title{
Jennifer Baker
}

\section{Autoethnography as creative expression: What my story could have been...}

\section{Abstract}

This paper explores how I am using creative expression combined with autoethnography and feminist theory to fulfil my PhD project objectives. My television drama series examines sexism, gender roles and gender-assigned occupations. Autoethnography uses the researcher's story and often stories of others alongside theory to encourage social change, and forms part of the writing methodology for my project. Autoethnographic stories rely on memory and discretion, therefore 'truth' is not necessarily essential or possible, and so I discuss 'truth' in relation to belief and knowledge, as discussed by current researchers of the theories of Heidegger and Foucault. Spurred on by writers who desire to create work that is inclusive and accessible, I chose creative expression in the form of a fictional television series to attract a wider audience and encourage social change. I refer to current feminist writers who critique post-feminism, with its questionable claims that equality has been achieved, its tendency towards individualism rather than group activism, and its lack of political content. Butler's concept of performativity in relation to fictional female business owners is discussed in relation to my female protagonists who, as a motivated group, enter a male-dominated industry.

Keywords: autoethnography, feminism, practice-led research

\section{Introduction}

De Freitas and Paton discuss 'artful' or 'arts-based' autoethnographies, which 'celebrate the fictional element of self-writing and ... trigger questions about experience and self-knowledge' (De Freitas \& Paton 2009: 489). My practice-led PhD project uses creative expression in the form of a televisior drama series, combined with autoethnography and feminist theory, to address my project objectives. Both autoethnography and feminist theory incorporate self-stories, and it is $m y$ story and my lifelong relationship with feminist ideals that provided motivation for the project. The project examines sexism, gender roles and gender-assigned occupations, as exemplified by the Australian music industry. My primary objectives are for jobs tr be seen as jobs, not 'male' or 'female' jobs; and to allow women entering male-dominated industries to adapt methods to suit both their style of working, and their female bodies. These objectives are strongly connected to the ever-elusive achievement of gender equality, which is the ultimate goal of feminism. The television series has four female protagonists who enter the male-dominated music industry in Sydney in the 1980 s and function as successful technicians and businesswomen. The four women are based on me and three women I met at a sound engineering course in the 1980 s. From a feminist point of view, the fictionalised story explores what might have happened had the four of us joined forces on completion of the course.

This paper examines the methodologies undertaken for the project, the use of fiction as a tool for encouraging social change, and how the belief that something could be true may play a role in acquiring knowledge.

\section{Autoethnography}

Autoethnography is 'research (graphy) that connects the personal (auto) to the cultural (ethnos), placing the self within a social context' (ReedDanahay 1997: 145). Autoethnographers have struggled for recognition in academic circles, but although there is still some reluctance for its acceptance as a legitimate research methodology it is now quite well-established and is gaining wider acceptance.

Ellis and Bochner (2000) list more than thirty terms (fiction and non-fiction) that might be labelled autoethnography, and as Laurel Richardson says,

What I am so excited about for contemporary qualitative research is how the forms have burgeoned. How there are so many different ways in which people can tell their stories... In most universities, you don't have to do that five-chapter discipline thing. You can alter that. You can really expand and do different things. (Richardson qtd in Ellis et al 2008: 278-9)

Loftsdóttir says with autoethnography, 'the researcher has to position her or himself in relation to the subject matter right from the beginning, critically asking why she has selected that particular topic of investigation' (Loftsdóttir 2011: 201). For me there was never any question about my interest in gender issues. I have always deplored gender stereotypes and assigned gender roles, and have never allowed them to affect my decisions related to an occupation or activity. Nothing would give me greater pleasure than to see gender stereotypes and assigned gender roles either diminish or disappear completely. Although I cannot see this happening during my lifetime, it is not going to stop me from trying to encourage their elimination in the future.

Sparkes criticises those who continue to label autoethnography as self-indulgent and asks, why not label these works as 'self-knowing, self-respectful, self-sacrificing, or self-luminous?' (Sparkes 2002: 210). He notes the tendency for all autoethnography to be labelled by its critics as self-indulgent 'regardless of the qualities of any individual venture', which he finds 'a dangerous and threatening move' (213). According to advocates of autoethnography (including Ellis \& Bochner 1996; Mykhalovskiy 1996; and Tsang 2000) we are all part of a culture, so any self-story is still going to be connected to that culture and others within it. Therefore the claim of self-indulgence 'become[s] absurd' (Sparkes 2002: 218). Sparkes also suggests $(2000 ; 2002)$ that it may be the criteria used for reviewing autoethnography that could be at fault and may therefore need to be revised.

When I first considered autoethnography as a methodology for my project it was in relation to my experiences in the 1980s when I encountered three young women in my practical class at a sound engineering course. Because my experience in the music and other male-dominated industries would not adequately demonstrate the project objectives, I decided fictionalising the story would be the best option. I could also protect the privacy of others whose stories overlapped with mine. Motivated by my growing interest in scriptwriting, a television drama series seemed the most appropriate creative medium. I have no idea what happened to those three young women, but they became the inspiration for three of my protagonists, alongside me as the fourth.

I wondered if there were any reasons why fiction would be inappropriate for my project. As with any research relying on stories of researchers or participants, the concept of truth is muddied. With memory, there is always an element of doubt regarding accuracy. Two or more people can have vastly different recollections of an event but to each their account is the 'truth'. Truth is not always paramount when stories are told, because how the audience reacts to a story may be what ultimately gives it value. Individuals may gain knowledge or understanding of an issue and this may lead some of them to change attitudes or take action. This is how social change might be achieved using stories, whether fiction, non-fiction, or versions of the 'truth'. 
Theoretical debate about truth has raged for centuries. Roman Emperor and Stoic philosopher, Marcus Aurelius said 'Everything we hear is an opinion not a fact. Everything we see is a perspective, not the truth' (Aurelius n.d.). One could argue for or against this statement, as with any philosophical proclamation. By writing my script I am expressing my opinion about a range of issues, and what I write is from my own perspective, or what I see as 'my truth'. Others may see things differently.

Zangwill argues that knowledge does not depend on truth. He concludes it is belief, rather than truth that should be focussed on and says 'knowledge depends on beliefs plus facts plus something else; truth depends on the facts; but knowledge does not depend on truth' (Zangwill 2013: 4). My emphasis should therefore be on providing knowledge to my audience by making them believe that what I have written could have happened.

Simpson discusses Foucault's later work on parrhesia, which is defined as 'speaking truthfully'. 'Foucault introduces parrhesia as a disposition to speak honestly to both oneself and others' (Simpson 2012: 100) and 'in enacting parrhesia, one speaks a truth which is often contradictory to the present state of affairs and therefore potentially undesirable' (101). I have proof, from the literature (Bailey 1999; Saraiva 2004; Smith 2011), from personal observation and from speaking to women who have worked in the industry, that the music and film industries in Australia are male-dominatec and sexist. In the fictional world of my television series, my female protagonists run a successful PA company. Although there $i s$ a female in Sydney who in the 1980s set up and still runs a PA company (employing both females and males, as there were never enough females working in the industry to sustain an all-female company), the technical side of the industry has always been seen as a male domain. My series will contradict this notion, but in such a way that, even with the threat of being 'potentially undesirable' to some members of the audience, there is also the possibility of changing attitudes.

Dreyfus, talking to Bryan Magee in a broadcast for the BBC Education and Training division (1987), mentions Heidegger's notion of 'authenticity', or doing what is deemed suitable in Western society. For example, as technology is deemed 'male' (apart from household appliances) perhaps some audience members might deem it unsuitable for a woman to take on a technical role such as sound engineer. These audience members can only know what has been disclosed to them as part of their 'being'. If I disclose to them the 'truth' that females are capable of working with technology, then perhaps authenticity will be changed for them. As a parrhesiastes (speaking truthfully, or what is my truth - that women can be successful technicians and entrepreneurs) I can demonstrate through the actions of my protagonists, that gender-assigned occupations may not have the authenticity that has been bestowed on them.

Discussing Foucault's ideas on 'truth' and fiction, Simpson says: 'For Foucault ... fiction holds a decided advantage over "truth", in that it constructively imagines an alternative interpretation of the present that exploits unexplored potentialities' (Simpson 2012: 105). He concludes:

While many have read parrhesia as a primarily pedagogical and external practice relating to the present, when read against Foucault's complicated conceptions of truth and fiction, parrhesia becomes a way of creating practices which destabilise the present and reveal potentialities for future action. (Simpson 2012: 114)

Although my series is set in the 1980s, issues concerning stereotypes, gender roles and sexism are still confronting Australians daily, in a range of industries (as is evidenced in mainstream and online media). If I am able to persuade some of my audience to believe my 'alternative interpretation', then this may potentially lead to some positive results in the future.

We only acquire knowledge from what others tell or show us (or what we observe around us). Wrathall notes: 'Two of the best-known features of Heidegger's thought are his analysis of truth in terms of disclosure and uncovering, and his insistence on the fact that we always live in, and encounter the world out of, an understanding of being' (Wrathall 2002: 217).

Dreyfus, in his talk with Bryan Magee (1987), says we only really become conscious of something when there is a problem. For example, on a simplistic level, I am a touch typist so my fingers automatically hit the correct keys on my computer keyboard without me consciously thinking about it. I have a ten inch netbook which I use when I travel. The keyboard is smaller than a regular-sized one, so because of this 'problem', I constantly hit wrong keys. I therefore become conscious of where my fingers are falling, in order to correct this 'problem'. In relation to my project, if members of my audience have never seen or heard of a female sound engineer, being confronted by female sound engineers in the series may constitute a problem for them initially. In the script several characters question if female sound engineers exist, and are told the truth: that there are some, but not many. I then show in the story that these women are perfectly capable of doing the job, despite any obstacles they encounter. The 'truth', as demonstrated in this fictional story, is that there is no reason why a female with the right skillset cannot do the job 'sound engineer'. The 'problem' for those audience members might therefore be resolved.

My four protagonists join forces to run a fictional small business. This business is based on an actual company run by a young male (overseen by his step-father and mother) in the 1980s. As Phillips and Knowles say:

The usefulness of fictional accounts depends on their apparent truth-to-life in a certain context so that the analysis of the ways in which characters and their fictional worlds are coded and constructed offers opportunities to interpret and reinterpret textual and extra-textual representations of organisation. (Phillips \& Knowles 2012: 417)

My aim is to implant the notion that the fictional business shown in the television series could function in the real world.

There are 'real' events and characters in my script, but these have been altered for confidentiality and in order to highlight the project objectives. From reading anecdotes in the literature and talking to women who have worked in the industry, it is very clear that many women 'just put up with' certain behaviours from males, in order to survive in the music industry. A few anecdotal incidents include: a female musician being stopped from going backstage to set up when arriving at a gig (guitar case in hand), after being assumed to be a groupie, and then being confronted with a sign backstage saying 'No females past this point'; a female sound engineer being told she could only use a piece of equipment in return for sexual favours; and an all female band unloading their own gear (not being deemed worthy of help from road crews) having an amp dropped on purpose from the back of a truck by a male crew member working for another band. Sound editor Annabelle Sheehan, in an interview recalls being told that she had been recommended for a job because 'she's got big tits and you'll probably like her' (Bailey 1999: 88). After putting up with numerous acts of unfitting behaviour from males she worked for and with, she now regrets 'not pointing out to them how inappropriate they were' (88). She also says 'It's sad that even with a sense of feminism a woman knows she will not easily find work if she complains' (88-89). Even after the introduction of the Sex Discrimination Act 1984 in Australia, the Human Rights Commission webpage states: 'Despite being outlawed for over 25 years, sexual harassment remains a problem in our workplaces' (Human Rights Commission 2013). This is unacceptable and I attempt to address the issue in my drama series by showing how my protagonists react to incidents of inappropriate behaviour. For example, when faced with increasingly bad behaviour during their first recording sessior at their sound engineering course, one of the female characters orders the band to leave, without the demo tape they should have received at the end of the night's recording. In another incident (borrowed from the tale of the dropped amp above), one of the women is able to repair the broken amp before the gig starts after the offending male is sent home by the tour manager. Interestingly, when I wrote the scene about the dropped amp, the response fron a male reader was 'That's a bit puerile, isn't it?' Of course it is. But this is the type of behaviour that women have experienced and 'just put up with' in order to work in the industry.

\section{The audience}

I relate strongly to the increasing number of researchers who embrace writing for a wider audience to encourage social change. For example, Brooks says, 
Part of my responsibility as a scholar is to make the world of ideas as inclusive and accessible as possible, not to exclude anyone from the conversation. One of my goals is to write something academic and popular audiences can read with enthusiasm. (Brooks 2006: 203)

And Doty says, 'Autoethnography has the potential to ... connect with our readers in ways that may make them care' (Doty 2010: 1050). Like Brooks and Doty, I want my project to be something a wide academic and non-academic audience will understand, enjoy, and care about.

I chose creative expression in the form of a fictional story because my actual story would not make an interesting television series and also, those parts of my story relating to my project objectives did not always have the best outcomes. I needed some positive outcomes for my characters, to address those objectives. What is essential is that (in line with my previous discussion about belief, truth and knowledge) everything I create is believable, appealing and worthwhile, and could have happened, under the right circumstances.

\section{Stories matter}

Everyone has a story, and each story matters, although some may be perceived as more interesting or socially significant, than others. Stories frame ou social awareness and result in our social concepts. The more stories we hear, the more we add to our knowledge and understanding, which may encourage us to change our way of thinking about a social issue.

Reading autoethnographies can have a range of effects. A reader with little or no experience of the issue may gain knowledge and understanding. A reader who has experienced the issue may empathise, and recognise similarities to their story, or may be surprised to find their story is quite different. Whether for reasons of similarity or difference, a reader may be stimulated to write their own story. For example, one of Ellis's (2004) students, Phillip (1999) was prompted to write her autoethnography about domestic violence, because after reading the literature she felt that no-one was writing her story. Another of Ellis's students Macleod (2000), a breast cancer survivor, was encouraged to include her story in her research project and she discovered, 'autoethnography provided a way of telling my story and freed me to think that I had a story worth telling. I came to see my story as one that could stand alone yet, like a ribbon or thread, also weave through and connect with other women's stories' (Ellis 2004: 294).

We need to hear stories and reflect on self-stories, to understand how we come to our social concepts, and why these might not necessarily match those around us. One example of this is perceptions related to gender in science, technology and maths. Palermo et al state: 'Despite some progress in recent years, achieving gender equality in scientific research remains an important challenge for policy-makers and the scientific community at large' (Palermo et al 2008: 494). Science and technology are considered 'male' domains in our society and science and maths are considered to be 'male' subjects in schools (despite girls often doing as well or better than boys). Andersson points out that even now in Sweden, a country 'which is considered one of the most gender-equal countries in the world' (Andersson 2012: 282), teachers

still had difficulty abandoning their stereotypical ideas about girls and boys. They reproduced the notion that there are gender differences in how children work with science and portrayed girls' activities as subordinate to boys'. (Andersson 2012: 299)

Guimond and Roussel, studying gender stereotypes related to maths, science and language, noted that 'men are seen as more able than women in math and science while women are seen as more able than men in language' (Guimond \& Roussel 2001: 277). Even though 'these beliefs have no basis in facts', they ask: 'Why do women not use the evidence from their own successful classroom performance in maths and science to dispel the myth that males are better?' (277). They conclude that because stereotypes tend to be believed, female students often downplay their strengths, and male students often exaggerate theirs, leading to stereotypical myths being perpetuated.

That science and maths are 'male' subjects or that males are better at these subjects was never $m y$ lived experience, so I find it difficult to accept as $m y$ 'given'. I went to an all-girls school where high achievement was paramount, and where you were either good at maths and science, or you were not. I1 my original career as a research scientist, gender was never an issue for me, either during my studies, or in the workplace. If I had never heard that 'scientist' is a male-dominated occupation, then my truth, that 'scientist' is not a gender-assigned occupation, would remain my 'truth' because that wa my experience. I am therefore faced with two opposing concepts: that jobs are 'male' or 'female'; or that a job is just a job that a male or a female may choose. My experience and observations have led me to believe the latter, which is one reason why I am undertaking my research project. In line with Heidegger's 'being', my being a scientist provided me with the understanding that I was doing a job that both males and females were suited to. I can now 'speak truthfully' (in keeping with Foucault) in my fictional television series, to persuade others that a job does not have to be assigned a gender.

In my television series I address issues of sexism, gender roles and gender-assigned occupations using my experiences from the 1980s including: my original career as a research scientist; the sound engineering course I completed with an all-female practical class; my enrolment in Stage I of an Electronics Engineering Certificate (as sole female in my class); and three years assisting my then-boyfriend/husband, a sound engineer, at gigs in Sydney. Although I was good at my research job, I decided I did not want to do it anymore. I was always weak in physics (not a female thing - many males are weak in physics too) so while I did well in Stage I of the Electronics Engineering Certificate, Stage II was completely beyond me. And despite my enthusiasm, I just would not have made a good sound engineer. My television series is what my story could have been, 'If I was more... If had enough... If I could have...' and so on. I can make my characters do anything I feel highlights my objectives, and this is both advantageous for my project, and empowering for me as creator. For example, I have retained the Electronics Engineering Certificate, but I did not give it to the character based on me. One of the other characters completes this course, and she is an absolute electronics whiz. She also seems to have stolen my addiction to chocolate. Because much of what I have written in the scripts actually happened, I can be confident that I am 'speaking truthfully' (or what I know as 'my truth') about my project issues and if this encourages my audience to change their perception about sexism, gender roles or gender-assigned occupations, then there may be the potential for future action, as Simpson (2012) discusses in relation to Foucault

\section{Feminism and My Story}

\section{(Don't tell me I can't do that because I'm a girl!)}

Autoethnography and feminist theory sit comfortably beside each other, as much feminist research begins with personal stories. For example, Ackerly and True discuss 'consciousness-raising' from the 1960s and 1970s, when groups of women gathered together to tell stories from their own lives, and state that consciousness raising: 're-valued personal experience and private thoughts and feelings as not separable from politics or society, but containing important information about what was social and political' (Ackerly \& True 2010: 465).

Social media is now playing a huge role in disseminating stories and highlighting a resurgence of feminist activism. Valenti mentions her friend, Amanda Marcotte, blogger for Pandagon.net who 'says that blogging is a great way to look at feminist activism, especially because it's the realisation of the old feminist adage "the personal is political"' (Valenti 2013: 186). She quotes Marcotte as saying that blogs "tear down so many of the obstacles that made it hard for individual women's stories to get an audience' (186). These days, it is possible that many potential feminists have gained valuable insight into feminism by reading stories online.

My ingrained concepts on sexism, gender roles and gender-assigned occupations were entrenched from a very early age. I grew up during second-wavt feminism which began in the 1960s as:

a social movement engaged in struggles over a range of issues such as reproductive rights, equal pay for equal work, domestic and sexual violence, and the sexual division of labour ... the popular was seen as a site for the cultural reproduction of gender inequalities'. (Hollows \& Moseley 2006: 4) 
Even before my awareness of the Women's Movement my thoughts about gender roles were well-established. My mother studied architecture (a maledominated occupation), so I had proof a woman could go to university and could study what she liked. My first childhood hero was Marie Curie, a scientist with two Nobel Prizes. Once again, although I was aware that 'scientist' was considered a male occupation, I had evidence a woman could be a scientist and indeed, could excel. Observations such as these led me to ignore stereotypes and assigned gender roles when very young. When others believe stereotypes, and adhere to their assigned gender roles it can be counterproductive to society's progress.

Although many women and men are capable of working in roles currently assigned to the other gender, it does not necessarily mean that $I$ was always capable of working successfully in ones I chose. This is why my real story would not be useful for this project and I have created more successful outcomes for my protagonists.

\section{Third-wave and post-feminist niggles}

Gender equality has not yet been achieved, either globally or in Australia, despite the valiant attempts of first-, second- and third-wave feminists. Although this may be disputed by some, there is enough evidence in texts, government reports, and mainstream and online media to substantiate the assertion. For example, the Workplace Gender Equality Agency's Gender Pay Gap Statistics (2013) show that the gender pay gap in Australia stood at 17.6 per cent as of November 2012. This had not changed since 2004, and was hardly an improvement from the early 1980 s, when it stood at about 20 per cent. And more recently, the COAG Reform Council Report Tracking equity: Comparing outcomes for women and girls across Australia released on 20 November 2013 (COAG Reform Council 2013) corroborated the 2012 figure.

Looking at how Australia fares in relation to gender equality, on a global scale is disheartening, but not surprising (to me, at least). The Global Gender Gap Index, introduced by the World Economic Forum in 2006:

$$
\begin{aligned}
& \text { is a framework for capturing the magnitude and scope of gender-based disparities and tracking their progress. The Index } \\
& \text { benchmarks national gender gaps on economic, political, education and health criteria, and provides country rankings } \\
& \text { that allow for effective comparisons across regions and income groups, and over time. (World Economic Forum 2013:3) }
\end{aligned}
$$

There are countries that have made more progress than others towards gender equality (notably the Scandinavian countries, which have remained at th top since the Index was started), but Australia is not one of them. According to the World Economic Forum's 2013 Global Gender Gap Report, in the latest Index, Australia has slipped from a ranking of number 15 in 2006 to number 24 in 2013.

Second-wave feminists seemed to have been making some progress in the 1970s and 1980s (with equal pay for equal work, sexual discrimination and sexual harassment legislation being introduced, for example), so what has gone wrong? The same issues second wave feminists struggled against, including equal pay, violence against women, reproductive choice, and division of domestic labour, are still issues today. Galloway concludes that women are still basically tethered to the home, so 'their engagement as empowered citizens in political, legal, economic, social and cultural terms is limited' (Galloway 2013). I interpret this as saying that the harried working woman, rushing home from work, picking up the kids from childcare on the way, stopping at the supermarket to pick something up for dinner, driving the kids to after-school activities, and so on, is still very much a reality, even if some men have started to take on some responsibility for these duties.

Harris has a rather disheartening interpretation of third-wave feminism, stating: 'More than 10 years after the publication of key so-called third-wave texts such as Generation f, Listen Up! and To Be Real, the idea of an even loosely organised movement of young females seems to have disintegrated' (Harris 2010: 475) which she attributes in part to the:

shift in social justice away from collective, hierarchical, state-oriented phenomena towards transitory engagements, heterogeneous movements and personal activities ... [that] leaves us with the image of feminism entirely mainstreamed and its political content removed or marginalised, the atomisation of feminist practice and the widespread disavowal of the feminist label. (Harris 2010: 247)

Both McRobbie (2009) and Scott (2010) also critique post-feminism, noting its claim that feminism is no longer relevant, as equality has apparently somehow miraculously been achieved, even though nothing has really been done to make it happen. McRobbie also describes a 'new kind of sophisticated anti-feminism ... [which] upholds the principles of gender equality, while denigrating the figure of the feminist' (McRobbie 2011: 179) and says individualism has now replaced the group activism of second-wave feminism.

Conversely, Aune criticises those (and in particular, McRobbie) who fail to 'recognise that some young women are feminists and are engaging in feminist political activism' (Aune 2013: 50). Although they may not call themselves feminists, they still may actively promote feminist ideals. I am of two minds here. I cannot claim that there is a lack of feminist activity or activism in our current society, because there are some wonderful young feminists talking and writing about feminist issues. Mainstream and online media is full of women (and men), both young and old, decrying misogyny, sexism and other gender issues. But as I said above, gender equality has still not been achieved, so this leaves the question: Why?

Current feminist texts such as Manifesta (Baumgardner \& Richards 2010), Renewing Feminisms (Thornham \& Weissmann 2013), Full Frontal Feminism (Valenti 2013) and How To Be a Woman (Moran 2012) are full of advice about what women should or should not be doing in order to achieve gender equality, or to empower themselves. Advocates of 'Girlie' feminism Baumgardner and Richards, defend their right to encompass 'tabooed symbols of women's feminine enculturation - Barbie dolls, makeup, fashion magazines, high heels - and says using them isn't shorthand for "we've been duped"“ (Baumgardner \& Richards 2010: 136). And their assertion is perfectly rational. However, Valenti is far more astute:

Wear high heels, mascara, and whatever else you want. I sure do. But let's not forget that by doing this we are adhering to a narrow, male-created vision of hotness. Again, this isn't to say it's wrong to want to look "hot", and to go along with the status quo from time to time, but let's not call it empowered. Call it what it is - fun and easy. (Valenti 2013: 251)

'Feminist' is a label many shy away from. Moi says most of her Feminist Classics students initially denied being feminists, until she asked 'if they are in favour of freedom, equality, and justice for women' (Moi 2006: 1735). Once they understood, they acknowledged they were feminists, but refused ts be labelled as such, as 'other people would think they must be strident, domineering, aggressive, and intolerant, and, worst of all, that they must hate men' (Moi 2006: 1736). One of my objectives is to make feminism less repellent to my audience, so Gervais and Hoffman's paper: 'Just Think About It: Mindfulness, Sexism, and Prejudice Toward Feminists' proved illuminating. Mindfulness 'has been conceptualised as non-judgemental attention an awareness to the present moment ...' (Gervais \& Hoffman 2013: 284). Gervais and Hoffman's findings 'suggest that mindfulness may contribute to less prejudice toward women because it motivates men to think and behave in less sexist ways toward women' (292). If I can write in a way that encourages my audience to be mindful about feminism and sexism, my objectives may be achieved.

My protagonists start out identifying with feminist ideals, but do not know much about feminism per se. They learn more about it over time, mainly ou of curiosity, after being referred to as 'bloody feminists' when they enter the male-dominated music industry. I am trying to introduce, in a nonthreatening manner, the notion that feminism is really just about gender equality, and that this is not a bad thing.

If gender equality is to become a reality, then no business should be restricted to one gender. I felt it necessary that the women start their business as an all-female enterprise in order to demonstrate that they were capable of doing the job, but once established they should become 'co-ed', with strict guidelines (for all employees) about sexism and sexual harassment in the workplace. 
When I grew up observing the women's movement I agreed with its ideals, but because I always considered myself equal to a male, I never felt the need to call myself a feminist. Why would I need to fight for equality when I was already equal? It took a while to realise this was rather self-centred, and just because $I$ regarded myself as equal and did not accept gender roles and stereotypes, it did not mean that gender equality is a 'given' for others. One reason I find post-feminist individualism so frustrating is perhaps because it reflects my younger self. I attended a panel discussion on feminism at the 2012 Byron Bay Writer's Festival. An older panellist mentioned the disparity between male and female pay in her male-dominated industry. A younger panellist stated that when she was working in a recent job she asked for a pay rise, and got it. Her argument on this panel was that if other women asked for pay rises they, like her, would be given one. She used herself as an example to claim that pay disparity is not an issue. This is despite the figures quoted above, from the Workplace Gender Equality Agency web page (2013). This young panellist was looking at the issue as an individua rather than seeing the bigger picture that confronts a large number of women. Sometimes it is necessary to see things from the perspective of a group o to work as a group, in order to overcome obstacles. For example, the character based on me is not as physically strong as the other three women, but instead of excluding her from the job (as would most likely have happened in real life) they resolve the issue so that she is able to function as an effective member of the team.

Cantzler and Leijon suggest that 'team collaboration contributes to better performance ... the entrepreneur learns from other team members, and they learn from her ... different roles within the team complement one another' (Cantzler \& Leijon 2007: 743-4). This correlates with my four protagonists, who have different strengths and make use of these to form a proficient team and assist each other as necessary.

\section{Viva La Différence! \\ (Let me do it my way!)}

Writer and politician, Clare Boothe Luce said: 'Because I am a woman, I must make unusual efforts to succeed. If I fail, no one will say, "She doesn't have what it takes." They will say, "Women don't have what it takes"' (Luce n.d.) One excuse used to discourage women from male-dominated industries is that women (a huge generalisation) lack physical strength. An article in the Herald Sun (AAP 2011) mentions Lorraine Usher, a long-time employee of the Construction Forestry Mining and Energy Union. When told women would not be hired on a worksite because of heavy lifting, she found the smallest male on the same worksite and asked what he did if he could not lift something. He said he asked his bigger mates. "'Why, when a woman can't do something, is it seen as a reflection on all women when this isn't the case for men?" said Ms Usher' (AAP 2011). I wonder if female sound engineers would consistently receive help lifting heavy gear, without risk of negative comments. From my recollection, male musicians always helped male sound engineers carry gear at gigs when I was present. I am making a huge assumption, as I cannot prove this, but I suspect those with negative attitudes toward female road crew would use physical strength to validate their attitudes toward females invading their territory, rather than offering the assistance they would provide a fellow male. I have developed scenes in my scripts from stories I have heard or read, to illustrate sexist attitudes and behaviour in the industry, and to demonstrate that it is unacceptable and unnecessary.

Women entering male-dominated professions are often expected to act like their male counterparts, or become 'pseudo-men'. Walker describes her experience as a young journalist where she 'often adopted the ways of journalism with enthusiasm' (Walker, Geertsema \& Barnett 2009: 178) but later, as a feminist academic, saw 'those traditions ... as gendered - not an exciting test of mettle for "equal" entry into the boys' club but a patriarchal structure built on the language and ideology of the powerful' (178). Similarly, Taber in her autoethnography about serving in the Canadian Forces says

it is essential to prove that you can not only do your job but participate in or put up with masculine activities... This included behaviours such as drinking, swearing, making sexual innuendos, and watching pornographic movies. (Taber 2005: 294-5)

In contrast, Chisholm (2008) describes how, by establishing her own method of climbing, rather than trying to emulate the generally much bigger male climber's body, free climber Lynn Hill conquered a climb that no-one, female or male, had previously been able to. Not only do females and males often have physical differences, females often have different styles of thinking or working. Faulkner cites a study on technological design by Turkle and Papert (1990) who noted that when female students adopted their own approach to a project they 'often found themselves actively discouraged by teachers, forced to pursue this approach surreptitiously or unlearn it or give up on computing' (Faulkner 2001: 86). This could be one reason why females might not try technical occupations, which is counterproductive, because, as Faulkner says, 'many of the ways of thinking and doing, which w stereotypically deem feminine, are useful, if not essential in technical work: linguistic abilities in computer programming, for instance' (86). I do not want to portray my protagonists as 'pseudo-men'. I want to show them working out their own methods of functioning in their new career, without thes being seen as inferior or unacceptable. There are women who enter these professions who try to act like their male counterparts. I have included a minor character who acts more like 'one of the boys' than some of the boys. She is loud, drinks the boys under the table, and will not help other women, in case she loses the respect she thinks she has gained from males she works with. My four protagonists will not feel the need to act like this, and it will become obvious that they should not have to. In the end, this character is forced to give the women work with the bands she manages, simply because they are good at their job and the musicians want the best people available.

By fictionalising my story I can display my four protagonists as functioning businesswomen, who ultimately succeed in what is assumed to be a male domain. Phillips and Knowles discuss Butler's concept of performativity in relation to female business owners in three works of fiction. They say 'fiction can offer a way of challenging, as well as colluding in, dominant constructions of entrepreneurship' (Phillips \& Knowles 2012: 417). Men are traditionally seen as typical entrepreneurs, with female entrepreneurs regarded as oddities. In the novels Chocolat (Harris 1999), The Shipping News (Proulx 1994) and Back When We Were Grownups (Tyler 2002):

alternative models of simultaneously doing femininity and doing business ownership are worked through. In order to be accepted by readers as realistic and believable ... fiction has to draw on cultural constructions of doing womanliness, and ... doing business ownership. At the same time, authors of fiction use their knowledge and experience of the social world to present the reader with twists and surprises to arouse excitement, to make the familiar strange and make us look afresh at the world we live in. (Phillips \& Knowles 2012: 433)

This is my aim. I want to create protagonists who are likeable and believable and present alternatives to current social concepts, so that in time, our social world might change. I want to show that women can function in a role deemed 'male' if they are given opportunities to resolve issues that may hinder progress, and to make adjustments that will suit their style of working and their physical capabilities.

\section{Conclusion}

To move closer to gender equality, one thing we need to do is eliminate gender-assignation from occupations and activities, which is one objective of my PhD project.

I have discussed how autoethnography and feminist theory complement each other. Using these two methodologies I was able to reflect on how my ingrained concepts on social issues were formed, and how these affect my knowledge, beliefs and concept of 'truth'. Looking at research into the work of philosophers such as Heidegger and Foucault convinced me that fictionalising my story was a valid method with which to express the project objectives. Belief is more important than truth when it comes to gaining knowledge.

Using creative expression, I have directed my script towards my project objectives relating to sexism, stereotypes and gender roles. I have attempted to write in a style that might encourage mindfulness in my audience and make them want to either think about, or instigate social change. I want my audience to empathise with my protagonists, and thereby encourage the notion that feminism is just about gender equality, rather than being an 
offensive term, as deemed by many. If I can persuade at least some audience members to try something they might otherwise not have; or others to accept women and men into industries or activities previously deemed for the other gender, then I feel this would be an achievement.

I could have chosen traditional memoir, or a true-life documentary for my creative artefact, but these would not have the same potential as a fictional television drama series. For my project, showing how things were would not be as effective as how things could have been and could still be, both currently and in the future.

By writing this paper, I hope to broaden knowledge and understanding of autoethnography as a methodology and show how it can be expressed creatively (for example, as a fictional television series), to encourage social change.

\section{Works cited}

AAP 2011 'Women can hold own in male industries but still face barriers', Herald Sun: http://www.heraldsun.com.au/archive/news/women-can-hold-own-in-male-industries/storyfn7x8me2-1226190290637 (accessed 1 August 2013) return to text

Ackerly, B \& J True 2010 'Back to the future: Feminist theory, activism, and doing feminist research in an age of globalization', Women 's Studies International Forum 33, 5: 464-72 return to text

Andersson, K 2012 “'It's funny that we don't see the similarities when that's what we're aiming for" - Visualizing and challenging teachers' stereotypes of gender and science', Research in Science Education 42, 2: 281-302 return to text

Aune, K 2013 'On pedagogy and feminist resurgence', in H Thornham \& E Weissmann (eds) Renewing Feminisms: Radical narratives, fantasies and futures in media studies IB Tauris, London return to text

Aurelius, M n.d. 'Marcus Aurelius Quotes': https://www.goodreads.com/author/quotes/17212.Marcus_Aurelius (accessed 10 August 2013) return to text

Bailey, J 1999 Reel women: working in film and television, Australian Film, Television and Radio School, North Ryde NSW return to text

Baumgardner, J \& A Richards 2010 Manifesta: Young Women, Feminism and the Future, Farrar, Straus \& Giroux, New York return to text

BBC 1987 Bryan Magee talks to Hubert Dreyfus about Husserl, Heidegger and modern existentialsim, BBC Education and Training, London return to text

Brooks, M 2006 'Man-to-Man', Qualitative Inquiry 12, 1: 185-207 return to text

Cantzler, I \& S Leijon 2007 'Team-oriented women entrepreneurs: a way to modern management', Journal of Small Business and Enterprise Development 14, 4: 732-46 return to text

Chisholm, D 2008 'Climbing like a girl: An exemplary adventure in feminist phenomenology', Hypatia 23, 1: 9-40 return to text

COAG Reform Council, 2013 Tracking equity: Comparing outcomes for women and girls across Australia:

https://www.coagreformcouncil.gov.au/sites/default/files/files/Tracking\%20equity\%2C\%20Comparing\%20outcomes\%20for\%20women\%20and\%20girls\%20across\%20Australia.p (accessed 22 November 2013) return to text

De Freitas, E \& J Paton 2009 '(De)facing the self’, Qualitative Inquiry 15, 3: 483-98 return to text

Doty, RL 2010 ‘Autoethnography - making human connections', Review of International Studies 36, 4: 1047-50 return to text

Ellis, C 2004 The Ethnographic I : A Methodological Novel About Autoethnography, Ethnographic alternatives book series, AltaMira Press, Walnut Creek CA return to text Ellis, C \& A Bochner (eds) 1996 Composing Ethnography, AltaMira Press, Walnut Creek CA return to text

Ellis, C \& A Bochner 2000 ‘Authoethnography, personal narrative, reflexivity: Researcher as subject', in N Denzin \& Y Lincoln (eds), Handbook of Qualitative Research 2nd edn, Sage, Thousand Oaks CA: 733-68 return to text

Ellis, C, A Bochner, N Denzin, Y Lincoln, J Morse, R Pelias \& L Richardson 2008 ‘Talking and Thinking About Qualitative Research’, Qualitative Inquiry 14, 2: 254-84 return to

Faulkner, W 2001 'The technology question in feminism: A view from feminist technology studies', Women's Studies International Forum 24, 1: 79-95 return to text

Galloway, K 2013 'The unwritten rules', Griffith Review 40: http://griffithreview.com/edition-40-women-power/the-unwritten-rules. (accessed 14 August 2013 ) return to text

Gervais, S \& L Hoffman 2013 'Just Think About It: Mindfulness, Sexism, and Prejudice Toward Feminists', Sex Roles 68, 5-6: 283-95 return to text

Guimond, S \& L Roussel 2001 'Bragging about one's school grades: Gender stereotyping and students' perception of their abilities in science, mathematics, and language', Social Psychology of Education 4, 3-4: 275-93 return to text

Harris, A 2010 'Mind the gap', Australian Feminist Studies 25, 66: 475-84 return to text

Harris, J 1999 Chocolat, Black Swan, London return to text

Hollows, J \& R Moseley (eds) 2006 Feminism in Popular Culture, Berg, Oxford return to text

Human Rights Commission 2013 'Sexual harrasment in Australia': https:/www.humanrights.gov.au/sexual-harassment-australia (accessed 19 November 2013) return to text

Loftsdóttir, K 2011 'Feminist Theory and that Critical Edge', NORA: Nordic Journal of Women's Studies 19, 3: 198-204 return to text

Luce, CB n.d. 'Clare Booth Luce Quotes': http://womenshistory.about.com/cs/quotes/a/qu_clare_luce.htm (accessed 1 August 2013) return to text

Macleod, V 2000 'Getting it off our chests: Living with breast cancer survival', PhD thesis, University of Florida return to text

McRobbie, A 2009 The Aftermath of Feminism: Gender, Culture and Social Change, Sage, Thousand Oaks CA return to text

McRobbie, A 2011 'Beyond post-feminism', Public Policy Research 18, 3: 179-84 return to text

Moi, T 2006 “"I am not a feminist, but...”: How feminism became the f-word', PMLA 121, 5: 1735-41 return to text

Moran, C 2011 How to be a Woman, Ebury Publishing, London return to text

Mykhalovskiy, E 1996 'Reconsidering table talk: Critical thoughts on the relationship between sociology, anthropology and self-indulgence', Qualitative Sociology 19: 131-51 returr to tex

Palermo, S, E Giuffra, V Arzenton \& M Bucchi 2008 'Gender and science', EMBO Reports 9, 6: 494-5 return to text

Phillips, M \& D Knowles 2012 'Performance and Performativity: Undoing Fictions of Women Business Owners’, Gender, Work \& Organization 19, 4: 416-37 return to text

Phillips, P 1999 'Illusions, fantasies, dreams, and reflections: An autoethnography of abuse', unpublished paper return to text

Proulx, EA 1994 The Shipping News, Fourth Estate, London return to text

Reed-Danahay, D 1997 Autoethnography, Berg, New York return to tex 
Saraiva, M 2004 Woman on the Job: Sound Engineer: http://www.shamelessmag.com/issues/2004/summer/woman-job-sound-engineer/ (accessed 13 October 2012) return to text

Scott, DT 2010 'The postfeminist user', Feminist Media Studies 10, 4: 457-75 return to text

Simpson, Z 2012 'The truths we tell ourselves: Foucault on parrhesia', Foucault Studies 13: 99-115 return to text

Smith, LM 2011, 'Sound Check', Black Enterprise 42, 5: 43-4 return to text

Sparkes, AC 2000 'Autoethnography and narratives of self: Reflections on criteria in action', Sociology of Sport Journal 17, 1: 21-43 return to text

Sparkes, AC 2002 'Autoethnography: Self-indulgence or something more?', in AP Bochner \& C Ellis (eds), Ethnographically speaking: Autoethnography, literature, and aesthetics, AltaMira, New York: 209-32 return to text

Taber, N 2005 'Learning how to be a woman in the Canadian Forces/unlearning it through feminism: an autoethnography of my learning journey', Studies in Continuing Education 27, 3: 289-301 return to text

Thornham, H \& E Weissmann (eds) 2013 Renewing feminisms: Radical narratives, fantasies and futures in media studies, IB Tauris, London return to text

Tsang, T 2000 'Let me tell you a story: A narrative exploration of identity in high-performance sport', Sociology of Sport Journal 17: 44-59 return to text

Turkle, S \& S Papert 1990 'Epistemological pluralism: Styles and voices within the computer culture', Signs: Journal of Women in Culture and Society 16, 1: 128-57 return to text

Tyler, A 2002 Back When We Were Grownups, Vintage, London return to text

Valenti, J 2013 Full Frontal Feminism: A Young Woman's Guide to Why Feminism Matters, Seal Press, Berkeley CA return to text

Walker, DL, M Geertsema \& B Barnett 2009 'Inverting the inverted pyramid: A conversation about the use of feminist theories to teach journalism', Feminist Teacher 19, 3: 177-94 return to text

Workplace Gender Equality Agency 2013 'Gender pay gap statistics’: http://www.wgea.gov.au/sites/default/files/2013-02-Gender\%20pay\%20gap\%20statistics.pdf. (accessed 19 November 2013) return to text

World Economic Forum 2013 'The Global Gender Gap Report': http://www3.weforum.org/docs/WEF_GenderGap_Report_2013.pdf. (accessed 5 November 2013) return to text

Wrathall, MA 2002 'Heidegger, truth and reference', Inquiry: An interdisciplinary Journal of Philosophy 45, 2: 217-28 return to text

Zangwill, N 2013 'Does knowledge depend on truth?', Acta Analytica 28, 2: 1-6 return to text

Jennifer Baker is a postgraduate student at Southern Cross University, Coffs Harbour. Her research interests include sexism, gender roles and gender equality. Her initial career was as a research scientist, but she changed direction, completing a BA in Communication Studies and Visual Arts and Design, at the University of New England, receiving the university's Art Prize in 1997. She subsequently completed an MA in Writing at Swinburne University of Technology, where she discovered the joys of scriptwriting and practice-led research.

\section{TEXT}

Vol 18 No 1 April 2014

http://www.textjournal.com.au

General Editor: Nigel Krauth. Editors: Kevin Brophy \& Enza Gandolfo

text@textjournal.com.au 